\title{
HOPLOPLEURA JANZENI N. SP. (PHTHIRAPTERA: ANOPLURA), A NEW SUCKING LOUSE FROM A CENTRAL AMERICAN SWIMMING MOUSE
}

\author{
Lance A. Durden and Robert M. Timm \\ Institute of Arthropodology and Parasitology, Georgia Southern University, P.O. Box 8056, Statesboro, Georgia 30460. e-mail: Idurden@gsvms2. \\ cc.gasou.edu
}

\begin{abstract}
Both sexes of a new species of sucking louse Hoplopleura janzeni (Phthiraptera: Hoplopleuridae) are described and illustrated from the Central American ichthyomyine swimming mouse Rheomys raptor (Rodentia: Muridae) collected in Costa Rica. The morphology of the new species is compared with that of Hoplopleura exima Johnson, the only other species of sucking louse known to parasitize an ichthyomyine rodent. Hoplopleura janzeni is unique in having posteriorly directed spurs on the first antennal segment, the fore- and midcoxae, and the hind femora of both sexes.
\end{abstract}

Members of the sucking louse genus Hoplopleura (Hoplopleuridae) are widely distributed on rodents worldwide and on pikas in central Asia, with 146 species recognized as ectoparasites of Echimyidae, Muridae (Arvicolinae, Cricetinae, Dendromurinae, Gerbillinae, Murinae, and Sigmodontinae), Octodontidae, Sciuridae, and Lagomorpha (Ochotonidae) (Durden and Musser, 1994; Durden, 2001). A distinctive new species of Hoplopleura was recently discovered on the Central American swimming mouse Rheomys raptor (Goldman) in the cloud forests of Costa Rica's Cordillera de Tilarán. This collection represents the first record of any parasite on a member of the sigmodontine genus Rheomys, which are all highly aquatic mice with specialized fur. The purpose of the present paper is to describe and illustrate this distinctive new species of Hoplopleura, to compare it to previously described species of Hoplopleura (particularly to a similar species from a related swimming mouse), and to comment briefly on its host relationships and unique morphology.

\section{MATERIALS AND METHODS}

The descriptive format followed in this paper is that of Durden and Webb (1999), which was based on that of Kim and Ludwig (1978). Names and abbreviations for setae follow those 2 papers and are spelled out in full when first mentioned in the present paper. Louse specimens were cleared in $10 \%$ potassium hydroxide, dehydrated through a series of ethanol washes of ascending concentration, further cleared in xylene, and then slide-mounted in Canada balsam following standard procedures (Kim et al., 1986). Specimens were measured with a calibrated eyepiece graticule fitted into a high-power Olympus BH-2 light microscope. Drawings were prepared with the aid of a Leitz PRADO 500 microprojector.

\section{DESCRIPTION}

\section{Hoplopleura janzeni $\mathrm{n}$. sp.} (Figs. 1, 2)

Male (Fig. 1A-D): Total body length, $1.02 \mathrm{~mm}$. Head, thorax, and abdomen moderately sclerotized.

Head longer than wide, broadly rounded anteriorly; 3 or 4 apical head setae (ApHS), 1 dorsal preantennal head seta (DPaHS), 2 supraantennal head setae (SpAHS), 2 sutural head setae (SuHS), 3 dorsal marginal head setae (DMHS), 1 long dorsal principal head seta (DPTS), 1 short dorsal accessory head seta (DAcHS), and 1 dorsal posterior central head seta (DPoCHS) dorsally on each side; 1 DMHS inserted anteriorly and close to dorsal head suture and 2 DMHS inserted posteriorly and lateral to DPHS; 3 or 4 ApHS, 2 ventral preantennal head setae (VPaHS), and 1 fairly long ventral principal head seta (VPHS) ventrally on each side.

Received 12 April 2001; revised 11 June 2001; accepted 11 June 2001. * Natural History Museum and Department of Ecology and Evolutionary Biology, University of Kansas, Lawrence, Kansas 66045-7561.
Antennae 5-segmented with basal segment larger than other segments and slightly longer than wide; first antennal segment with small posterior spur.

Thorax longer than wide with margins tapering anteriorly. Thoracic sternal plate (Fig. 1B) club-shaped with rounded anterolateral margins, broadly acuminate anterior apex, and elongate posterior extension with squarish posterior apex. Mesothoracic spiracle diameter, $0.023 \mathrm{~mm}$. Dorsal principal thoracic seta (DPTS) length, $0.123 \mathrm{~mm}$; no other thoracic setae present except on legs. Legs progressively larger from anterior to posterior, all with subtriangular coxae proximally and acuminate claws terminally; forecoxae with narrow spur-like ridge posteriorly; midcoxae with broad spur-like ridge posteriorly; hind femora with relatively broad spur-like ridge posteriorly.

Abdomen wider than thorax. Ventrally, with 1 small sternite on segment 1; 2 elongate sternites (nos. 2 and 3) on segment 2, each articulating with corresponding paratergal plate as is characteristic of Hoplopleura; 1 sternite (no. 4) on segment $3 ; 2$ sternites on each of segments 4-6; sternite 1 lacking setae; sternite 2 with 6 sternal abdominal setae (StAS) with 2 lateral StAS on each side slightly thickened; sternite 3 with 6 StAS with narrow central setae and stout lateral setae (2 on 1 side, 3 on the other); sternites 4-10 each with 6-8 StAS; some central StAS distinctly shorter than lateral StAS. One ventral lateral abdominal seta (VLAS) lateral to sternite 10 on each side. One small lobe with small seta, medial to paratergal plate I dorsally on each side; 1 relatively broad tergite on each of abdominal segments 2-7; tergites 1 and 2 each with 4 tergal abdominal setae (TeAS); tergites 3-6 each with 8-11 TeAS; some TeAS on tergites 3-5 of different lengths (Fig. 1A). Six short subterminal setae and 8 apical setae dorsally on each side. Paratergal plates (Fig. 1C) present on segments 1-8; plates I-VI subtriangular; plate I relatively small and lacking setae; plates II-VI each with 2 apical setae of moderate length and about equal in size; plates VII and VIII each with 2 long apical setae; plates II-VI each with fluted sculpting on posterolateral lobulated apices; plates III-VII each with moderately sized spiracle; all plates differentially sclerotized as shown (Fig. 1C).

Genitalia (Fig. 1D) with basal apodeme about twice as long as parameres; parameres relatively broad and curved, tapering posteriorly; pseudopenis fairly long, extending beyond apices of parameres, with distinctly pointed posterior apex, slightly thickened, undulating subapical lateral margins, and small subapical medial crenulations. Subgenital plate (shown in Fig. 1A) extending anteriorly to abdominal segment 7, with undulating lateral margins that diverge posteriorly; 1 narrow, broad medial lacuna anteriorly with 2 long setae inserted anteriorly on each side; 1 larger, broad medial lacuna posteriorly with 1 long seta inserted anteriorly on each side.

Female (Fig. 2A-D): Total body length, $1.23 \mathrm{~mm}$. Head, thorax, and abdomen as in male unless indicated otherwise.

Thoracic sternal plate (Fig. 2B) similar to that of male but with broadly rounded anterior apex. Spur on hind femora longer than in male, curved and terminating in acuminate apex.

Abdomen wider than thorax; 1 small sternite ventrally on segment 1 ; 2 broad sternites (nos. 2 and 3) on segment 2, each articulating with corresponding paratergal plate as is characteristic for Hoplopleura; 3 long, narrow sternites on each of segments 3-6; 1 narrow sternite on segment 7. Sternite 2 with 9 StAS consisting of 3 stout lateral StAS on each side and 3 narrow StAS centrally, with single midline StAS short; sternite 3 with 7 StAS, all relatively long, and with 2 lateral StAS on 

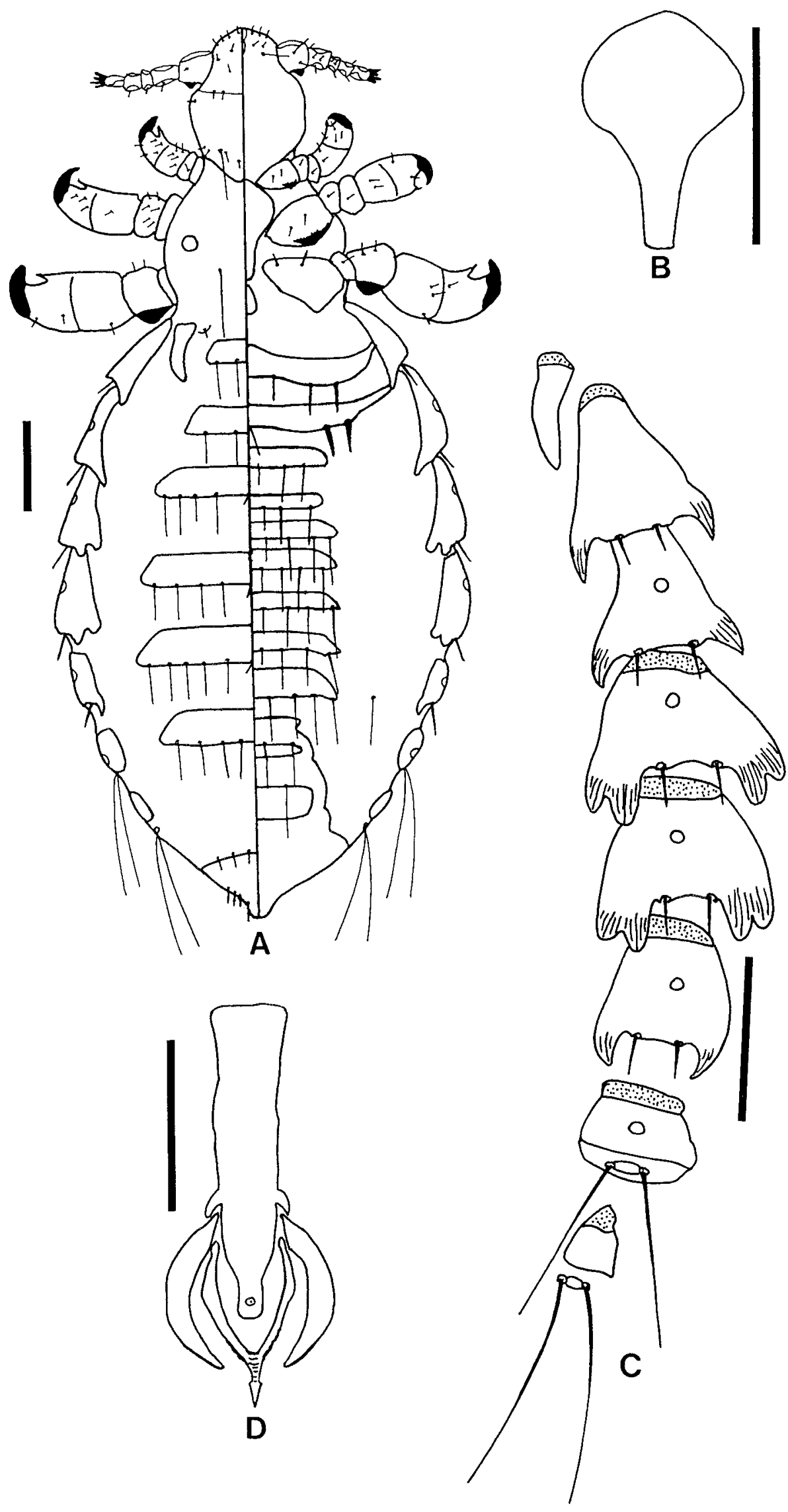

Figure 1. Hoplopleura janzeni n. sp. male. A. Dorsoventral view. B. Thoracic sternal plate. C. Paratergal plates. D. Genitalia. Scale bars $=$ $0.1 \mathrm{~mm}$. 


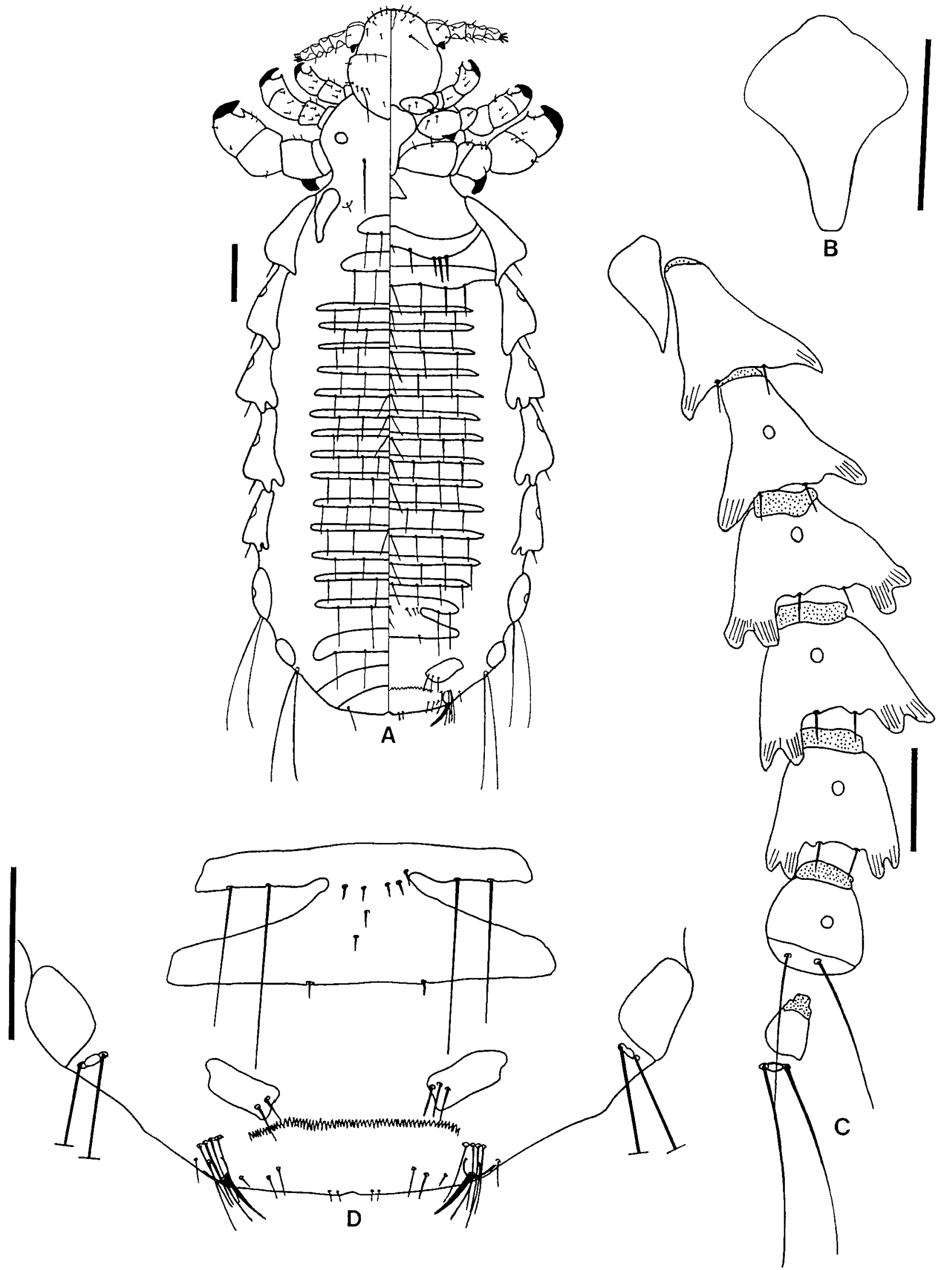

Figure 2. Hoplopleura janzeni n. sp. female. A. Dorsoventral view. B. Thoracic sternal plate. C. Paratergal plates. D. Genitalia. Scale bars $=0.1 \mathrm{~mm}$. 
each side slightly thickened; sternites 4-16 each with 5-7 StAS of moderate length and thickness. One small lobe with small seta, medial to paratergal plate I dorsally on each side; 2 relatively broad tergites (nos. 1 and 2) on segment 2; 3 narrow tergites on each of segments $3-$ $6 ; 2$ narrow tergites on segment $7 ; 1$ relatively broad tergite on segment 8. Tergites 1,2 , and 17 each with 4 long TeAS; tergites 3-16 each with 4-6 shorter TeAS; 1 relatively short terminal seta on each side dorsally. Paratergal plates (Fig. 2C) similar to those of male except for plate I, which is broadly subtriangular, plate VI, which has lobulated posterolateral apices, and plate VII, which is suboval in shape.

Genitalia (Fig. 2D) with well-sclerotized, broad subgenital plate with deep anterolateral indentation on each side; 2 long setae inserted on anterior arm of subgenital plate on each side; 7 small setae arranged more or less centrally and 1 small seta on each side on posterior margin of subgenital plate. Gonopods and vulvar fimbriae distinct; gonopods VIII broad, each with small anterolateral extension and 2 or 3 relatively small setae posteromedially; gonopods IX each with stout terminal seta; 3 rows of setae immediately anterior to gonopods IX on each side consisting of 4 (anterior row), 2 (middle row), and 1 (posterior row) setae, respectively; 1 seta inserted immediately lateral to gonopods IX on each side; several small to intermediate-sized setae present between gonopods IX.

\section{Taxonomic summary}

Type host: Rheomys raptor hartmanni Enders ( $q$, University of Kansas Natural History Museum, KU 159017).

Type locality: Costa Rica: Prov. Puntarenas; Monteverde, Monteverde Cloud Forest Reserve, elevation 1,500 m $\left[10^{\circ} 18^{\prime} \mathrm{N}, 84^{\circ} 47^{\prime} \mathrm{W}\right], 23$ October 2000; coll: Robert M. Timm, RMT 4495.

Specimens deposited: Holotype (female) and allotype male deposited in U.S. National Museum of Natural History, Smithsonian Institution, Washington, D.C. (type no. 105742).

Etymology: This species is named in honor of Daniel H. Janzen in recognition of his pioneering studies on the ecology, taxonomy, and conservation of the Costa Rican biota.

\section{Remarks}

Hoplopleura janzeni can be distinguished immediately from other species of Hoplopleura by the presence of spurlike extensions on the first antennal segment, the fore- and midcoxae, and the hind femora in both sexes. Based on host associations and morphology, H. janzeni appears to be most closely related to Hoplopleura exima Johnson, which is only known from the unique male holotype (Johnson, 1972). Both $H$. janzeni and $H$. exima have a protuberance on the hind femora; however, this is merely a low ridge in $H$. exima but is a well-developed spur in $H$. janzeni, especially in the female. Unlike $H$. janzeni, H. exima does not have protuberances or spurs on the first antennal segments or on the fore- and midcoxae.

Other differences between the males of these 2 species include the following. (1) The shape of the thoracic sternal plate: this is suboval with a pointed posterior apex in $H$. exima, but more club-shaped, with a distinct posterior extension and a straight posterior margin in $H$. janzeni. (2) The shape of the paratergal plates: plates IV and V have nonlobulated broad apices in $H$. exima but are distinctly lobulated in $H$. janzeni. (3) The setation of the paratergal plates: plates IV-VI each have 1 short seta and 1 seta of moderate length in $H$. exima but have 2 setae both of moderate length in $H$. janzeni. (4) The shape of the subgenital plate: this has 1 wide lacuna and margins tapering posteriorly in $H$. exima, but 2 wide lacunae and margins diverging posteriorly in $H$. janzeni. (5) The position of the parameres: these barely extend laterally beyond the lateral margins of the basal apodeme in $H$. exima but extend laterally to a distance about equal to the width of the basal apodeme in $H$. janzeni. The shape of the pseudopenis also probably differs between the 2 species, but it is damaged in the holotype of $H$. exima and therefore cannot be used for comparison.

\section{DISCUSSION}

With the discovery of Hoplopleura janzeni on Rheomys raptor, there are now 2 species of sucking lice known to parasitize Neotropical ichthyomyine swimming mice. In a comprehensive monograph on the ichthyomyine rodents, Voss (1988) recognized 14 species in 5 genera in this highly specialized Neotropical endemic tribe. All species are poorly known and most are represented by few specimens in museum collections. The only species of louse previously known from an ichthyomyine is $H$. exima, which was described from the Venezuelan water rat Chibchanomys trichotis (Thomas) and is known by a single specimen (Johnson, 1972).

Rheomys spp. swimming mice are poorly known, highly aquatic mice that occur only at high elevations from Oaxaca, Mexico, through Central America to western Panama. Four species are recognized in the genus (Voss, 1988). Rheomys raptor is known by only 18 specimens from 5 localities in Costa Rica and Panama. In the Monteverde region, Timm and LaVal (2000) considered $R$. raptor to be rare. No species of ectoparasites or endoparasites had been known previously from any species of Rheomys. With the discovery that a unique species of sucking louse occurs on Rheomys raptor, additional species of lice, as well as other ectoparasites, should be sought on this interesting group of rodents.

Except for pinnipeds (seals, sea lions, and walruses) and the American river otter (Lontra canadensis), few aquatic mammals are known to be parasitized by sucking lice. The above-mentioned aquatic hosts are all parasitized by echinophthiriid sucking lice. The 12 known species of lice belonging to this family possess body scales or stout setae that aid in trapping an air bubble, which appears to act as a physical gill to aid respiration when their host submerges (Hinton, 1976). However, the spurs on $H$. janzeni do not appear to be sufficiently numerous to function in this way. Nevertheless, these spurs do presumably have adaptive significance. They could be used to aid in host attachment although, as in other sucking lice, the tibiotarsal claws which grasp individual host hairs probably represent the most important attachment device (Durden, 2001). It is also possible that the spurs play a role in the mating behavior of H. janzeni. If additional new species of lice are collected from swimming mice in the future, it will be of great interest to determine whether they possess spurs similar to those of H. janzeni.

\section{ACKNOWLEDGMENTS}

Rafael Bolaños, Director of La Reserva Biológica Bosque Nuboso Monteverde, and the Tropical Science Center, San José, Costa Rica, made our work in the Reserve possible. We thank Javier Guevara S., Ministerio del Ambiente y Energía and Sistema, for providing research permits. The Organization for Tropical Studies and Christy M. McCain greatly facilitated the work of R.M.T. in Costa Rica. A sabbatical leave for R.M.T was provided by the University of Kansas. Nancy Adams, of the U.S. National Museum of Natural History, Washington, D.C., arranged loans and assigned type numbers to louse material. Laboratory work at Georgia Southern University was facilitated by National Institute of Allergy and Infectious Diseases grant AI 40729.

\section{LITERATURE CITED}

Durden, L. A. 2001. Lice (Phthiraptera). In Parasitic diseases of wild mammals, W. M. Samuel, M. J. Pybus, and A. A. Kocan (eds.). Iowa State University Press, Ames, Iowa, p. 3-17.

- AND G. G. Musser. 1994. The sucking lice (Insecta: Anoplura) of the world: A taxonomic checklist with records of mammalian hosts and geographical distributions. Bulletin of the American $\mathrm{Mu}$ seum of Natural History 218: 1-90.

, AND J. P. WEBB. 1999. Abrocomaphthirus hoplai, a new genus and species of sucking louse from Chile and its relevance to zoogeography. Medical and Veterinary Entomology 13: 447-452. 
Hinton, H. E. 1976. Respiratory adaptations of marine insects. In Marine insects, L. Cheng (ed.). North Holland Publishing, Amsterdam and American Elsevier Publishing, New York, p. 43-78.

Johnson, P. T. 1972. Sucking lice of Venezuelan rodents, with remarks on related species (Anoplura). Brigham Young University Science Bulletin, Biological Series 17(5): 1-62.

Kim, K. C., AND H. W. Ludwig. 1978. The family classification of the Anoplura. Systematic Entomology 3: 249-284.

, H. D. Pratt, and C. J. Stojanovich. 1986. The sucking lice of North America: An illustrated manual for identification. The
Pennsylvania State University Press, University Park, Pennsylvania, $241 \mathrm{p}$.

Timm, R. M., AND R. K. LAVAL. 2000. Mammals. In Monteverde: Ecology and conservation of a tropical cloud forest, N. M. Nadkarni and N. T. Wheelwright (eds.). Oxford University Press, New York, p. 223-244, 553-560.

Voss, R. S. 1988. Systematics and ecology of ichthyomyine rodents (Muroidea): Patterns of morphological evolution in a small adaptive radiation. Bulletin of the American Museum of Natural History 188: $259-493$. 